\title{
EFEKTIFITAS PENGGUNAAN PLATFORM LMS UMM PADA PEMBELAJARAN JARAK JAUH DITENGAH PANDEMI COVID-19
}

\author{
Ahmad Alif Asy'ari Syukur, Wahyu Andhyka Kusuma \\ Universitas Muhammadiyah Malang (UMM) Jawa Timur, Indonesia \\ Email: ahmadalif523@webmail.umm.ac.id,wahyukusuma@umm.ac.id
}

\begin{tabular}{l}
\hline INFO ARTIKEL \\
\hline Diterima \\
25 Agustus 2021 \\
Direvisi \\
05 September 2021 \\
Disetujui \\
15 September 2021
\end{tabular}

\section{ABSTRAK}

Di masa pandemi seperti ini, kegiatan belajar mengajar hanya bisa dilakukan dari jarak jauh dan menggunakan platform seperti LMS UMM, namun beberapa pemangku kepentingan membutuhkan waktu untuk beradaptasi dengan metode ini. Biasanya juga ada beberapa mahasiswa yang mengalami

Kata Kunci: LMS; UMM; pembelajaran jarak jauh kendala saat mengakses sistem $L M S$ seperti mata kuliah yang tidak otomatis terdaftar dan juga beberapa kendala lainnya. Metode penelitian yang digunakan yakni metode studi literature, wawancara, dan mengumpulkan user persona dari stakeholder. Kemudian data yang diperoleh dari wawancara diolah dan dapat diketahui bahwa mahasiswa setuju dengan metode pembelajaran jarak jauh ini, namun beberapa mahasiswa masih mengalami kendala dan digunakan untuk menganalisis apakah platform LMS UMM dapat digunakan secara efektif dan mudah digunakan. Kesimpulan yang dapat saya ambil dari hasil data yang telah saya ambil adalah sistem LMS UMM cukup membantu dalam proses belajar mengajar namun efektivitasnya masih dapat ditingkatkan untuk memudahkan pengguna saat menggunakan LMS UMM. Hasil dari penelitian ini saya dapat mengetahui dimana biasanya mahasiswa mengalami kendala pada saat mengoperasikan platform LMS UMM.

\section{ABSTRACT}

During a pandemic like this, teaching and learning activities can only be done remotely and using platforms such as LMS UMM, but some stakeholders need time to adapt to this method. Usually there are also some students who experience problems when accessing the LMS system such as courses that are not automatically registered and also several other obstacles. The research method used is the method of literature study, interviews, and collecting user personas from stakeholders. Then the data obtained from the interviews were processed and it can be seen that the students agreed with this distance learning method, but some students still had problems 
and used it to analyze whether the UMM LMS platform could be used effectively and was easy to use. The conclusion that I can draw from the results of the data that I have taken is that the UMM LMS system is quite helpful in the teaching and learning process but its effectiveness can still be improved to make it easier for users when using the UMM LMS. The results

Keywords: LMS; of this study I can find out where students usually experience UMM; e-learning problems when operating the UMM LMS platform.

\section{Pendahuluan}

Penguasaan teknologi yang masih kurang oleh pihak dosen maupun mahasiswa tidak bisa dihindari, oleh karena itu moodle LMS yang digunakan harusnya memiliki tingkat efektifitas yang tinggi dan juga mudah untuk difahami. Platform seperti moodle $L M S$ ini juga memiliki peran penting dalam melancarkan proses pembelajaran jarak jauh dan juga fitur-fitur yang ada di dalamnya dapat membantu mahasiswa untuk mengefisiensi waktu (Kusuma \& Hamidah, 2020). Setelah kehadiran guru dalam arti sebenarnya, internet akan menjadi suplemen dan komplemen dalam menjadikan wakil guru yang mewakili sumber belajar yang penting di dunia (Materi \& Jawa, 2004).

Bagi mahasiswa, pembelajaran jarak jauh atau online memang sudah familiar. Hanya saja, teknis pembelajaran dan metode pembelajaran belum mampu memuaskan dosen dan mahasiswa itu sendiri. Meskipun banyak sekali platform pembelajaran yang tersedia antara lain seperti whatsapp, google classroom, zoom, sevima edlink, schoology dan masih banyak lagi (Alaby, 2020). Tentunya platform menjadi kurang efektif dalam penggunaannya dikarenakan oleh beberapa faktor antara lain kemampuan dosen maupun mahasiswa dalam mengoperasikannya tidaklah sama, selain itu kondisi geografis suatu daerah berbeda sehingga berpengaruh kepada kestabilan jaringan internet (Fanani \& Jainurakhma, 2020). Pada saat ini pemerintah sudah memberikan kompensasi untuk siswa / mahasiswa yang sedang menempuh pembelajaran secara online dengan cara memberi paket data untuk siswa / mahasiswa yang aktif itu merupakan Langkah awal yang bagus untuk mencapai tujuan proses Pembelajaran Jarak Jauh (PJJ). Perkuliahan online atau yang biasa disebut daring merupakan salah satu bentuk pemanfaatan internet yang dapat meningkatkan peran mahasiswa dalam proses pembelajaran (Saifuddin, 2018). Istilah daring merupakan akronim dari "dalam jaringan“. Jadi perkuliahan daring adalah salah metode pembelajaran online atau dilakukan melalui jaringan internet. Beberapa persyaratan pelaksanaan kuliah daring, antara lain: (a) pihak penyelenggara kegiatan kuliah daring, (b) mindset positif dosen dan mahasiswa dalam fungsi utama internet, (c) desain sistem proses belajar yang bisa dipelajari oleh semua mahasiswa, (d) adanya proses evaluasi dari rangkaian proses belajar mahasiswa, dan (e) mekanisme feedback dari pihak penyelenggaraan (Ningsih, 2020).

Virus corona atau yang biasa disebut covid-19 saat ini sedang merebak di Indonesia dan menyebabkan beberapa dampak yang besar dari segi Pendidikan, 
industry, maupun perekonomian. Wabah virus covid-19 dapat menular dengan sangat cepat menyebar hingga ke berbagai belahan dunia (Sari et al., 2020).Virus corona yang setiap hari semakin menyebar menjadikan pemerintah untuk memutuskan beberapa peraturan dan kebijakan baru kepada masyarakat. Kebijakan-kebijakan tersebut antara lain, yakni Gerakan social distancing, gerakan bekerja dan beribadah di rumah, online learning (pembelajaran online), serta PSBB (pembatasan sosial berskala besar) yang baru-baru ini sedang digalakkan (Astuti \& Prestiadi, 2020). Banyak institusi Pendidikan saat ini dengan memanfaatkan kecanggihan teknologi informasi mereka menerapkan system Pembelajaran Jarak Jauh (PJJ) untuk menunjang proses pembelajaran (Ninla Elmawati Falabiba, 2019). Banyak platform yang bisa digunakan untuk menunjang sistem pembelajaran tersebut diantaranya yakni moodle LMS yang digunakan oleh kampus Universitas Muhammadiyah Malang (UMM) sebagai platform untuk melakukan kegiatan belajar mengajar secara online dari jarak yang berjauhan. karena masyarakat Indonesia saat ini mayoritas sudah menggunakan Internet hal ini sesuai dengan penelitian We Are Sosial, "Digital Reports 2020" yang dirilis pada akhir Januari 2020 menyatakan hampir 64 persen penduduk Indonesia sudah terkoneksi dengan jaringan internet, jumlah penguna internet di Indonesia sudah mencapai 175,4 juta orang dari total jumlah penduduk Indonesia yang berjumlah sekitar 272,1 juta dan tahun 2019 lalu, jumlah pengguna internet di Indonesia meningkat sekitar 17 persen atau 25 juta pengguna (Pakpahan \& Fitriani, 2020).

Hasil dari penelitian yang kami harapkan yakni platform yang disediakan oleh pihak kampus seperti LMS dapat menunjang proses Pembelajaran Jarak Jauh (PJJ) dengan efektif dan efisien.

\section{Metode Penelitian}

Dalam pengumpulan data-data yang dibutuhkan guna menyelesaikan penelitian ini, peneliti menggunakan metode penelitian sebagai berikut :

1. Studi Literatur

Peneliti mendapatkan sumber data dari berbagai sumber dengan cara mengumpulkan referensi yang menunjang melalui buku, jurnal, majalah dan sumber lainnya yang mendukung penelitian, metode ini digunakan dalam pengumpulan data yang berkaitan dengan konsep E-learning yang berhubungan dengan Pemanfaatan Teknologi Informasi Dalam Pembelajaran Jarak Jauh.

2. Wawancara

Metode wawancara adalah metode pengumpulan data, dimana peneliti melakukan secara langsung wawancara terkait dengan pembelajan jarak jauh dan mengenai platform yang disediakan oleh kampus yakni moodle LMS dengan dosen dan mahasiswa Universitas Muhammadiyah Malang.

Pada tahapan ini peneliti kami melakukan beberapa wawancara kepada stakeholder-stakeholder seperti dosen dan mahasiswa, kemudian mereka akan memberikan pendapat mengenai platform LMS di Universitas Muhammadiyah Malang. Proses wawancara dilakukan melalui media video conference. 


\section{User Persona}

Tahapan ini membuat user persona berisi tentang dokumen persona yang menjelaskan deskripsi dari persona, deskripsi ini berisi komponen psikologi, motivasi, dan gaya hidup mereka (Warin et al., 2018). Komponen ini didapatkan dari tahapan-tahapan sebelumnya.

\section{Hasil dan Pembahasan}

\section{Hasil Studi Literature}

\section{a. Konsep Pembelajaran Jarak-Jauh}

Pembelajaran Jarak Jauh (PJJ) merupakan suatu system pembelajaran yang tidak berlangsung dalam satu ruangan dengan tatap muka antar murid dan guru (Padwa \& Erdi, 2021), namun sistem pembelajaran jarak jauh ini dibantu dengan teknologi dan platform yang telah disediakan oleh kampus yakni $L M S$. Berdasarkan hal tersebut, maka pembelajaran jarak jauh dilaksanakan tanpa adanya interaksi langsung secara fisik antara pengajar dan pembelajar, interaksi dilakukan pada sistem virtual dengan bantuan teknologi yang memungkinkan terjadinya interaksi dan penyampaian ilmu pengetahuan dari pengajar ke murid.

Sementara itu, pada penelitian yang dilakukan (Abdul Latip, 2020) menyebutkan bahwa selama masa pandemi Covid-19, proses pembelajaran dilaksanakan dengan sistem "Flexible Learning". Sistem ini memiliki beberapa ciri, yaitu 1) dimensi pembelajaran yang bisa dilaksanakan dimana saja dan kapan saja, 2) pembelajar bisa belajar apapun yang diinginkan, 3) sumber belajar bisa berasal dari pengajar langsung atau berbagai sumber yang tersedia pada berbagai media seperti web, 4) pengajar memiliki kesempatan yang banyak dalam menentukan pelaksanaan pembelajaran (tutoring, belajar mandiri, seminar, debat, dan diskusi secara online), dan 5) pada pelaksanaan penilaian bisa menggunakan sistem yang menyediakan fleksibilitas lebih bagi siswa dalam melaporkan setiap aktivitas yang dilaksanakan selama masa pandemi Covid-19. Disisi lain demi tetap menjaga dunia pendidikan bisa tetap berjalan dengan baik serta mendukung Pemerintah dalam mendukung Physical distancing ditengah Pendemi Covid 19 sesuai intruksi presiden untuk tetap dirumah, belajar dirumah, bekerja dirumah, ibadah dirumah (Pakpahan \& Fitriani, 2020).

\section{b. Faktor yang menentuka kesuksesan PJJ dimasa pandemi}

Pelaksanaan proses belajar mengajar secara daring pada masa pandemi perlu memperhatikan beberapa factor yang dapat mendukung Sistem Pembelajaran Jarak Jauh ini hingga lancar diantaranya yakni. Pengajar harus memiliki kemampuan dan keterampilan dalam menggunakan media penunjang pembelajaran, selain itu pengajar pun harus memiliki kreativitas dan pengalaman dalam melakukan serta mengemas interaksi virtual dengan para pembelajar. Semenatara itu pada faktor pembelajar yang akan berpengaruh terhadap pelaksanaan pembelajaran jarak jauh diantaranya kultur, latar belakang sosial ekonomi, interes, pengalaman dan tingkat pendidikan. Selanjutnya, faktor penentu 
keberhasilan pembelajaran jarak jauh lainnya adalah teknologi, teknologi merupakan media, alat dan sarana penunjang terjadinya proses interaksi antara pengajar dan pembelajar.

Pendapat lain menyebutkan terdapat lima faktor krusial yang dapat mendorong pada keberhasilan pembelajaran jarak jauh, yaitu 1) Manajemen institusi, 2) Lingkungan belajar, 3). Desain pembelajaran, 4) Layanan pendukung, dan 5) Evaluasi pembelajaran (Amil et al., 2020). Pada konteks pembelajaran jarak jauh selama masa pandemi Covid-19, kelima faktor tersebut tentu saja menjadi faktor yang bisa mendukung pelaksanaan PJJ. Faktor manajemen institusi berkaitan dengan desain perancanaan pelaksanaan PJJ di masa pandemi Covid-19 yang dirancang oleh institusi pendidikan pusat sampai Sekolah sebagai pelaksanaan di lapangan. Arahan kurikulum yang tepat dan terencana akan menjadikan pelaksanaan PJJ berjalan sesuai dengan harapan. Sejalan dengan hal itu, (Nugraheny, 2020) menyebtukan bahwa dukungan pihak manajemen pengelola pusat pendidikan menjadi salah satu penentu keberhasilan pembelajaran jarak jauh (E-learning).

\section{Hasil Wawancara}

Tabel 1

Pertanyaan wawancara

\begin{tabular}{cl}
\hline $\begin{array}{c}\text { No } \\
\text { Pertanyaan }\end{array}$ & \multicolumn{1}{c}{ Pertanyaan wawancara } \\
\hline 1 & $\begin{array}{l}\text { : Platform LMS memudahkan proses belajar } \\
\text { mengajar ? }\end{array}$ \\
\hline 2 & $\begin{array}{l}\text { : Pembelajaran secara online lebih baik } \\
\text { daripada tatap muka ? }\end{array}$ \\
\hline 3 & $\begin{array}{l}\text { : Platform LMS dapat menambah wawasan / } \\
\text { ilmu kita }\end{array}$ \\
\hline
\end{tabular}

Pada pengumpulan data melalui wawancara ke mahasiswa maupun dosen yang sekarang sedang menempuh proses belajar mengajar secara daring peneliti mengajukan pertanyaan seperti yang ada pada tabel 1. Kemudian jawaban dari stakeholder kami klasifikasikan menggunakan skala likert yakni : STS (Sangat Tidak Setuju), TS (Tidak Setuju), KS (Kurang Setuju), S (Setuju) dan SS (Sangat Setuju).

Tabel 2

Jawaban wawancara

\begin{tabular}{clccc}
\hline \multirow{2}{*}{ No } & \multirow{2}{*}{ Stakeholder } & Pertanyaan & Pertanyaan & Pertanyaan \\
& & $\mathbf{1}$ & $\mathbf{2}$ & $\mathbf{3}$ \\
\hline 1 & Dosen 1 & SS & TS & S \\
\hline 2 & Dosen 2 & S & KS & S \\
\hline 3 & Mahasiswa 1 & S & TS & KS \\
\hline 4 & Mahasiswa 2 & SS & TS & S \\
\hline
\end{tabular}

Dari tabel 2 diatas kita dapat mengambil kesimpulan bahwasanya proses Pembelajaran Jarak Jauh dengan menggunakan platform $L M S$ ini sudah cukup efisien namun apabila dibandingkan dengan proses pembelajaran secara tatap muka maka 
lebih baik dilakukan dengan tatap muka. Karena keterangan dari beberapa stakeholder bahwasanya pada saat tatap muka materi yang disampaikan oleh dosen lebih mudah diterima apabila pada saat pembelajaran secara online. Namun untuk sistem LMS sendiri menurut para stakeholder sudah sangat bagus dan membantu pada saat proses Pembelajaran Jarak Jauh dan juga memudahkan kita untuk mengikuti proses belajar mengajar pada saat pandemi saat ini. Untuk Analisa lebih lanjut kami dapat memastikan bahwasanya mahasiswa sangat terbantu dengan adanya platform seperti $L M S$ ini karena dapat menunjang pembelajaran pada saat pandemi.

\section{User Persona}

Hasil dari wawancara pada tahap sebelumnya, didapatkan berbagai komponen yang berguna dalam pembuatan user persona, seperti nama, roles, task, frustration, dan goals. Komponen-komponen ini nantinya akan dimasukkan kedalam sebuah dokumen persona seperti pada gambar 1 dan gambar 2 .

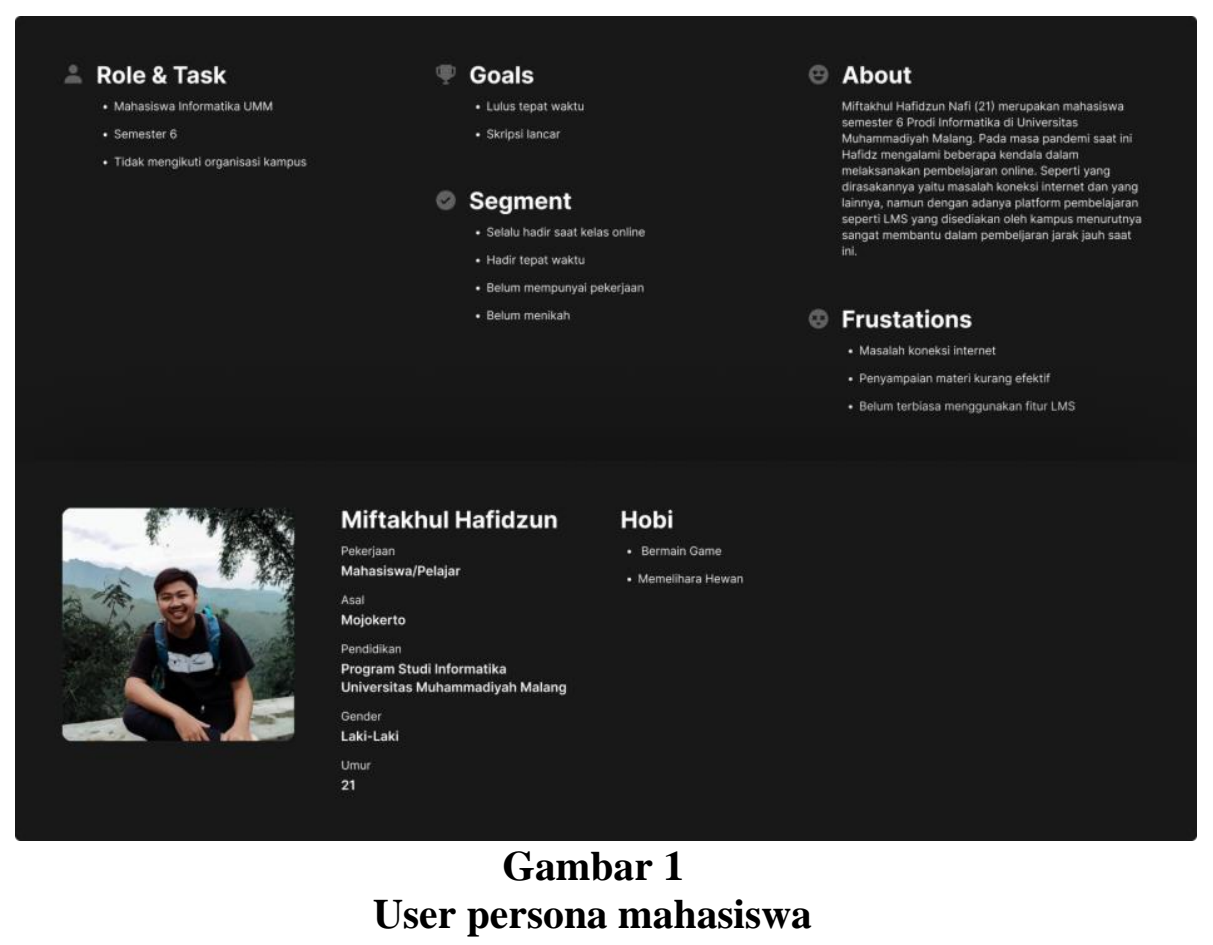




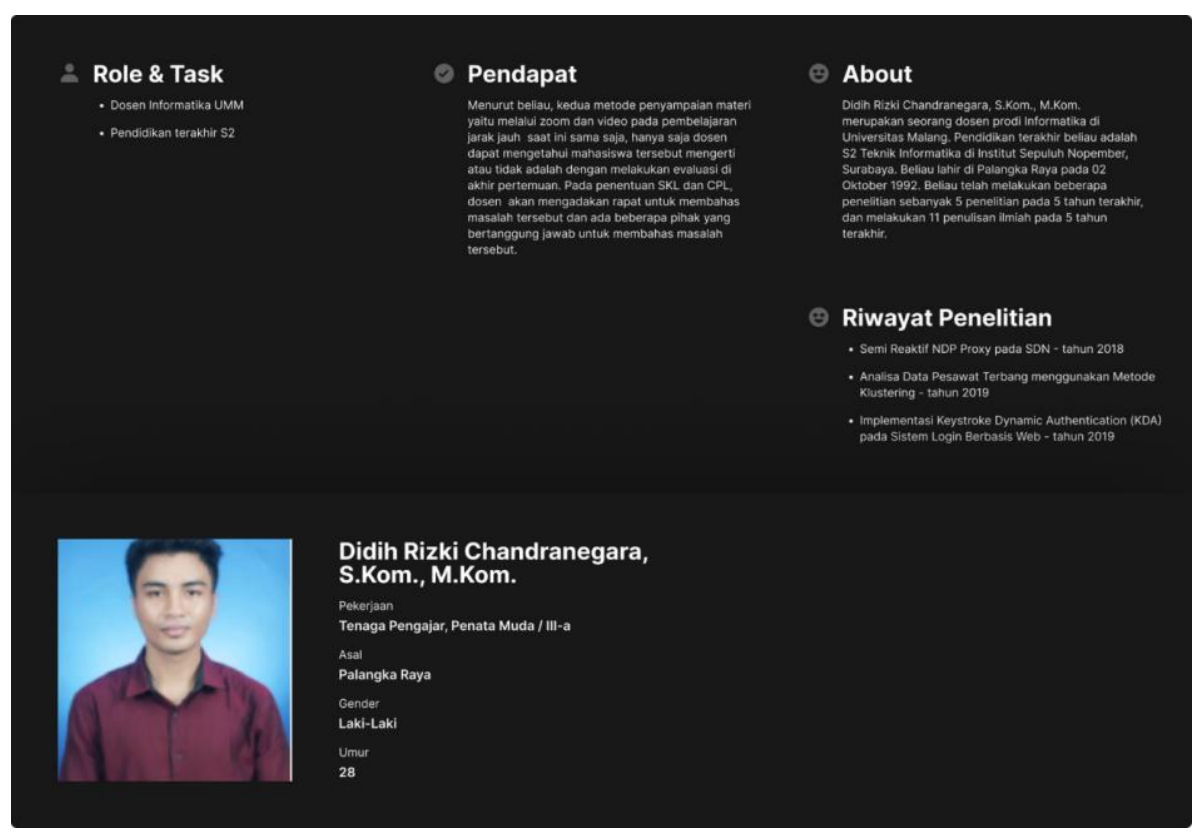

Gambar 2

\section{Solusi Dari Permasalahan}

user persona dosen

Dari permasalahan yang sudah didapat, supaya para stakeholder dapat lebih memanfaatkan platform LMS dengan efektif peneliti menyarankan supaya proses enrollment kelas dapat dilakukan secara otomatis tidak secara manual.

\section{Kesimpulan}

Kesimpulan yang saya ambil dari penelitian diatas yakni pada saat Proses belajar mengajar selama masa pandemi memang diperlukan platform untuk menunjang keberhasilan proses belajar mengajar seperti LMS UMM, oleh karena itu saya menggunakan beberapa metode penelitian untuk mengetahui bagaimana respon mahasiswa dan dosen yang bersangkutan mengenai platform LMS UMM tersebut. Hasil akhir penelitian saya ambil dari menganalisis data yang telah saya ambil adalah sistem LMS UMM cukup membantu dalam proses belajar mengajar namun efektivitasnya masih dapat ditingkatkan untuk memudahkan pengguna saat menggunakan LMS UMM. Hasil dari penelitian ini saya dapat mengetahui dimana biasanya mahasiswa mengalami kendala pada saat mengoperasikan platform LMS UMM. 


\section{BIBLIOGRAFI}

Abdul Latip. (2020). Peran Literasi Teknologi Informasi Dan Komunikasi Pada Pembelajaran Jarak Jauh Di Masa Pandemi Covid-19. EduTeach : Jurnal Edukasi Dan Teknologi Pembelajaran, 1 (2), 108-116. Google Scholar

Alaby, M. A. (2020). Media Sosial Whatsapp Sebagai Media Pembelajaran Jarak Jauh Mata Kuliah Ilmu Sosial Budaya Dasar (ISBD). Ganaya: Jurnal Ilmu Sosial Dan Humaniora, 3 (2), 273-289. Google Scholar

Amil, B., Nasional, Z., BAZNAS, Badan, K., Zakat, A., Republik, N., د, غسان., Badan Amil Zakat Nasional, Dana, L. P. L. D. A. N., Keuangaii, L., Beraktiir, Y., Relief, H., Hall, J. K., Weinberger, R., Marco, S., Steinitz, G., Moula, S., Accountants, R. P., Report, A. A. S., ... Eddy, S. A. (2020). No 主観的健康感を中心とした在宅 高齢者における 健康関連指標に関する共分散構造分析 Title. Journal of Chemical Information and Modeling, 21 (1), 1-9. Google Scholar

Astuti, A. D., \& Prestiadi, D. (2020). Efektivitas Penggunaan Media Belajar Dengan Sistem Daring. Prosiding Web-Seminar Nasional (Webinar) "Prospek Pendidikan Nasional Pasca Pandemi Covid-19" Fakultas Ilmu Pendidikan - Universitas Negeri Malang, August, 129-135. Google Scholar

Fanani, Q., \& Jainurakhma, J. (2020). Kemampuan Penyesuaian Diri Mahasiswa Terhadap Pembelajaran Daring Di Tengah Pandemi Covid-19. Jurnal KomtekInfo, 7 (4), 285-292. Google Scholar

Kusuma, J. W., \& Hamidah, H. (2020). Perbandingan Hasil Belajar Matematika Dengan Penggunaan Platform Whatsapp Group Dan Webinar Zoom Dalam Pembelajaran Jarak Jauh Pada Masa Pandemik Covid 19. JIPMat, 5 (1). Google Scholar

Materi, D., \& Jawa, A. (2004). Media pembelajaran berbasis. 319-326. Google Scholar

Ningsih, S. (2020). Persepsi Mahasiswa Terhadap Pembelajaran Daring Pada Masa Pandemi Covid-19. JINOTEP (Jurnal Inovasi Dan Teknologi Pembelajaran): Kajian Dan Riset Dalam Teknologi Pembelajaran, 7 (2), 124-132. Google Scholar

Ninla Elmawati Falabiba. (2019). 済無No Title No Title No Title. 1 (1), 9-18. Google Scholar

Nugraheny, A. R. (2020). Peran teknologi, guru dan orang tua dalam pembelajaran daring di masa pandemi. Peran Teknologi, Guru Dan Orang Tua Dalam Pembelajaran Daring Di Masa Pandemi, 7. Google Scholar

Padwa, T. R., \& Erdi, P. N. (2021). Penggunaan E-Modul Dengan Sistem Project Based Learning. JAVIT : Jurnal Vokasi Informatika, 1 (1), 21-25. Google Scholar 
Pakpahan, R., \& Fitriani, Y. (2020). Analisa Pemafaatan Teknologi Informasi Dalam Pemeblajaran Jarak Jauh Di Tengah Pandemi Virus Corona Covid-19. Jisamar (Journal of Information System, Applied, Management, Accounting and Researh), 4 (2), 30-36. Google Scholar

Saifuddin, M. F. (2018). E-Learning dalam Persepsi Mahasiswa. Jurnal Varidika, 29 (2), 102-109. https://doi.org/10.23917/varidika.v29i2.5637. Google Scholar

Sari, W., Rifki, A. M., \& Karmila, M. (2020). Pembelajaran Jarak Jauh Pada Masa Darurat Covid 19. Jurnal Mappesona, 1, 12. Google Scholar

Warin, B., Kolski, C., \& Toffolon, C. (2018). Living persona technique applied to HCI education. IEEE Global Engineering Education Conference, Educon, 2018-April, 51-59. https://doi.org/10.1109/EDUCON.2018.8363208. Google Scholar

\section{Copyright holder:}

Ahmad Alif Asy'ari Syukur, Wahyu Andhyka Kusuma (2021)

First publication right:

Jurnal Syntax Admiration

This article is licensed under: 